\title{
Covid-19: Increased demand for steroid inhalers causes "distressing" shortages
}

\author{
Elisabeth Mahase
}

The BMJ

Steroid inhaler manufacturers are experiencing "significant demand" as people in the UK try to stock up in light of the covid-19 pandemic, causing "distressing shortages," the Department of Health and Social Care has warned.

Several inhalers have been listed as out of stock by All About Health ${ }^{1}$ — which distributes pharmaceutical and healthcare products to pharmacies, hospitals, and doctors across the UK-including Clenil (beclomethasone) made by Italian pharmaceutical company Chiesi.

The British Thoracic Society warned that demand for inhalers had increased by $400 \%$. In guidance, the society advised clinicians to continue to write monthly repeat prescriptions rather than writing a prescription for several months. ${ }^{2}$ It said that doctors should encourage patients not to stockpile and should discuss with patients who have not ordered a repeat prescription for an inhaler for more than four months whether it was still clinically required.

The increased demand comes despite NHS England asking clinicians and patients last month not to over prescribe or over order during the pandemic. ${ }^{3}$ "We are aware there has been a significant increase in demand across a number of inhaler presentations, and we are working with suppliers to ensure supplies continue to remain available," a spokesperson for the Department for Health and Social Care told The BMJ.

Sarah MacFayden, head of policy and public affairs at the British Lung Foundation, said, "We have heard that some people with lung conditions have been experiencing problems getting hold of certain medicines, and this might be due to very high demand and potential distribution issues." She said, "We are urging everyone with lung conditions not to try to stockpile medicines during the coronavirus outbreak, get their prescriptions earlier than usual, or get more inhalers than they need. This won't be allowed and causes problems for others."

In a statement on its website, Chiesi said: "At present in the UK there is significant demand in the supply chain for all Chiesi respiratory products and this is leading to our wholesaler partners suffering from out of stock situations for many lines in many of their depots whilst they are waiting for replenishment of their stocks from Chiesi." ${ }^{4}$

1 All About Health. Out of stock notice board. 30 March 2020. https://www.aah.co.uk resource/blob/30378/32b6d37e991450ca3aac9860ac01c1f4/aah-out-of-stock-pharmacyand-dispensing-doctors-data.pdf

2 British Thoracic Society. BTS information: respiratory Inhalers. March 2020. https://www. google.. com/url?sa $=$ t\&rct=j\&q=\&esrc=s\&source $=$ web\&cd $=1 \&$

ved=2ahUKEwiz5o7IIMzoAhXJOcAKHfB2ADIQFjAAegQIAxAB\&url=https\%3A\%2F\% 2Fwww.brit-thoracic.org.uk\%2Fdocument-library\%2Fquality-improvement\%2Fcovid-19\% 2Fbts-information-respiratory-inhalers\%2F\&usg=AOvVaw2ttii-mv6pKluwTh32v1 A-

3 NHS England. 31 March 2020. https://www.england.nhs.uk/coronavirus/wp-content uploads/sites/52/2020/03/C0114-_Pharmacy-letter_no.-3_31-March.pdf

4 Chiesi. Information for healthcare professionals on the supply of Chiesi products. https:/ /www.chiesi.uk.com/supply-of-chiesi-products

Published by the BMJ Publishing Group Limited. For permission to use (where not already granted under a licence) please go to http://group.bmj.com/group/rights-licensing/ permissions 